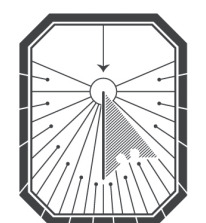

KYIV-MOHYLA

LAW \& POLITICS JOURNAL

KYIV-MOHYLA SCHOLARLY PEER-REVIEWED JOURNALS

\title{
Legal Challenges of the EU-Belarus Relations
}

Author(s): Maksim Karliuk

Source: Kyiv-Mohyla Law and Politics Journal 4 (2018): 65-79

Published by: National University of Kyiv-Mohyla Academy

http://kmlpj.ukma.edu.ua/ 


\title{
Legal Challenges of the EU-Belarus Relations ${ }^{1}$
}

\author{
Maksim Karliuk \\ Higher School of Economics, \\ Skolkovo Institute for Law and Development \\ Ghent University, \\ Department of European, Public and International Law
}

\begin{abstract}
EU-Belarus relations have seen many changes throughout the years ranging from closer engagement to isolation. Although recently the relations started to improve, the main international agreement between Belarus and the EU is still the one concluded by the Soviet Union. Even though there are plans on changing the situation and concluding a new international framework agreement with the EU, it is clear that Eurasian integration is of primary importance for Belarus. This article focuses on analyzing the legal basis of the EU-Belarus relations, effect that international contractual obligations have in the domestic legal order, and the way membership to the Eurasian Economic Union influences that. It is argued that new contractual legal framework between Belarus and the EU is imaginable, although it would be limited, among others, due to transfer of certain exclusive competences to the supranational level of the Eurasian Economic Union.
\end{abstract}

Key Words: EU, Belarus, neighborhood policy, international law, WTO.

\section{(2)}

\section{Introduction}

EU-Belarus relations have seen many changes throughout the years which have influenced the state of the contractual framework between the parties. In the mid-199os, the EU saw a deterioration of the political situation in Belarus and tried to exercise its influence in order to introduce legal and political change. The EU wanted Belarus to respect its international obligations to democracy, human rights, and the rule of law.

1 This article draws on the two previously published book chapters by this author:

Maksim Karliuk, "The Constitutional Order of Belarus and Its Adaptability to the Eurasian

Economic Union: A 'Living Constitution' Workaround, “in Post-Soviet Constitutions and

Challenges of Regional Integration: Adapting to European and Eurasian Integration Projects,

ed. R. Petrov and P. Van Elsuwege (Oxford: Routledge, 2018), 174-96; Maksim Karliuk,

"Legislative Approximation and Application of Eu Law in Belarus," in Legislative Approximation

and Application of Eu Law in the Eastern Neighbourhood of the European Union: Towards

a Common Regulatory Space?, ed. Roman Petrov and Peter Van Elsuwege (Oxford: Routledge,

2014), 203-18. 
It also sought full cooperation with the OSCE and more active engagement with the Council of Europe in the domains of their corresponding expertise. The EU applied different approaches to reach these aims, both separately and cumulatively, including conditionality, isolation, and restrictive measures. These approaches coincided with an intensification of relations with civil society. However, none of the approaches seem to have brought the results desired by the EU at the time. ${ }^{2}$

Later, following a short period of intensification of contacts, the EU became dissatisfied with the way the presidential elections were conducted in Belarus in 2010, which made doubtful the possibility of a positive change in Belarus. This led the EU to considerably expand its policy of restrictive measures towards certain Belarusian elites. $^{3}$ As a result, a number of cases were brought before the Court of Justice of the European Union against the Council of the EU questioning the legality of its decisions against Belarusian individuals and companies. ${ }^{4}$

However, more recently, the relations started to improve, since, in the view of the EU, Belarus introduced measures that were in line with the EU's vision. ${ }^{5}$ In particular, it manifested itself in the release of political prisoners and in presidential elections that were free from violence in 2015 , as well as, quite importantly, a rather neutral and helpful stance over the conflict in Ukraine. Belarus has been more proactive in the Eastern Partnership and the negotiations on the Mobility Partnership came to a positive conclusion. Belarus has also initiated the renewal of the annual EU-Belarus Human Rights Dialogue. Eventually, the EU lifted most of its restrictive measures in 2016. ${ }^{6}$ It has reinforced its financial support through the European Neighborhood Instrument and

$2 \quad$ For a detailed overview see e. g. Peter Van Elsuwege, "The European Union and the Belarus Dilemma: Between Conditionality and Constructive Engagement," Proceedings of the Institute for European Studies, Journal of Tallinn University of Technology 7 (2010): 7-20.

See "Belarus and the EU," accessed May 1, 2018, https://eeas.europa.eu/delegations/ belarus/15975/belarus-and-eu_en. An unprecedented number of people (including governmental officials, judges, and businessmen) were added to the list of admission restrictions and freezing of funds and economic resources. In addition, an embargo on arms and related materials, ban on exports of equipment for internal repression and ban on provision of certain services were introduced.

4 See Case T-441/11: Action brought on August 12, 2011-Peftiev v. Council. O. J. C 290, 01/10/2011 P. o017-0017.; Case T-438/11: Action brought on August 12, 2011-BelTechExport v. Council. O. J. C 29o, o1/10/2011 P. o015-0015; Case T-439/11: Action brought on August 12, 2011 — Sport-pariv. Council. O. J. C 290, o1/10/2011 P. o015-0016; Case T-440/11: Action brought on August 12, 2011BT Telecommunications v. Council. O. J. C 29o, o1/10/2011 P. 0016-0o17.

5 See "EU-Belarus Relations Fact Sheet," accessed May 1, 2018, http://eeas.europa.eu/delegations/ belarus/eu_belarus/political_relations/index_en.htm.

$6 \quad$ For a regularly updated full list of regulations and decisions introducing restrictive measures taken by the EU, including those against Belarus, see "European Union-Restrictive Measures (Sanctions) in Force," accessed May 1, 2018, http://eeas. europa.eu/cfsp/sanctions/docs/ measures_en.pdf. 
has removed textile quotas for exports. It is engaging more in economic cooperation, primarily through such institutions as the European Investment Bank, whose mandate has been extended to include Belarus, and the European Bank of Reconstruction and Development, which has extended its financing activities.

Nevertheless, the EU still has concerns over the situation with human rights and democracy (freedom of assembly and association, labor standards, freedom of speech and the media). In particular, Belarus is the only European country to apply the death penalty in practice. For these and other reasons, the EU-Belarus Coordination Group was established in 2016 as a forum for senior officials' policy dialogue. Belarus also adopted the "National Action Plan on Human Rights" in 2016. ${ }^{7}$

Regardless of these developments, the main international agreement between Belarus and the EU is still the one concluded by the Soviet Union. ${ }^{8}$ Even though there are plans on changing the situation and concluding a new international framework agreement with the EU, it is clear that Eurasian integration is of primary importance for Belarus. ${ }^{9}$ It has been for many reasons an eager proponent of closer integration with Russia and of Eurasian integration in general, which has led it to become the founding member of the Eurasian Economic Union (EAEU).

This article focuses on the following issues related to the EU-Belarus contractual relations. First, it provides an overview of the legal basis of the EU-Belarus relations. Second, it delves into the effect that international contractual obligations have in the domestic legal order of Belarus. This is necessary to understand how a possible EUBelarus agreement would work in practice. Third, it looks into the interesting case of the World Trade Organization law being applicable on the territory of Belarus, without it being a member thereof. This could be of importance for the EU even in the absence of formal contractual relations. Fourth, since Belarus is a member of the EAEU, it requires taking this into account when envisaging any kind of agreement between the EU and Belarus. Finally, some conclusions will be made on the prospects of contractual obligations between the two parties.

\section{Legal Framework of EU-Belarus Relations}

The Constitution of Belarus of 1994 (as amended in 1995, 1996 and 2004) formally recognizes the values common to the EU. The Constitution describes Belarus as a democratic state based on the rule of law where individual rights, freedoms, and the necessary guarantees to secure them are recognized as the supreme goal of society and

7 See "Human Rights," accessed May 1, 2018, http://mfa.gov.by/en/organizations/human_rights/.

8 Agreement Between the European Community and the European Atomic Energy Community and the Union of Soviet Socialist Republics on Trade and Commercial and Economic Cooperation, OJ, (1990): L 68/3.

9 See "Makei: Belarus Ready for New Framework Agreement with EU," accessed December 26, 2016, http://www.belta.by/politics/view/belarus-hochet-zakljuchit-s-es-novoe-soglashenie-dljarazvitija-otnoshenij-176293-2016/. 
the state. ${ }^{10} \mathrm{An}$ international agreement with the EU could possibly spur and promote these values.

However, the legal framework of EU-Belarus relations is rather limited and starts with the Trade and Cooperation Agreement (TCA) concluded by the then European Economic Community and the Soviet Union in 1989." The agreement was endorsed by Belarus after the dissolution of the USSR. The TCA was supposed to cease to exist pursuant to Article 108 of the Partnership and Cooperation Agreement (PCA) ${ }^{12}$ upon its entry into force. The PCA was indeed signed in 1995 and even ratified by Belarus. ${ }^{13}$ However, no ratification followed from the EU side due to a political setback in Belarus and, therefore, it is not in force to date. It should however be mentioned that Belarus does not rule out the possibility for this PCA to enter into force, and such prospect is even mentioned in the Concept of National Security of the Republic of Belarus which was adopted in 2010. ${ }^{14}$

The TCA is not comparable to the PCA as it is a trade agreement and does not provide for other commitments beyond that, in particular those of legislative approximation. It has rather modest objectives of promoting investment and economic co-operation in general, based on the principles of equality, non-discrimination and reciprocity. ${ }^{15}$ However, apart from this outdated TCA, there are no substantial bilateral agreements between the EU and Belarus. Only specific agreements are in force. ${ }^{16}$ In 2011 ,

10 The Constitution of the Republic of Belarus, adopted on May 15, 1994, No. 2875-XII (as amended by the republican referendums on November 24, 1996, October 17, 2004), Art. 1 and 2.

11 Agreement Between the European Community and the European Atomic Energy Community and the Union of Soviet Socialist Republics on Trade and Commercial and Economic Cooperation, OJ, (1990): L 68/3.

12 Proposal for a Council and Commission Decision on the Conclusion of the Partnership and Cooperation Agreement Between the European Communities and Their Member States, of the One Part, and Belarus, of the Other Part, of February 22, 1995, COM (95) 44 final.

13 Enactment of the Supreme Council of the Republic of Belarus "On Ratification of the Partnership and Cooperation Agreement Between the European Communities and their Member States of the One Part, and Belarus, on the Other Part," of April 12, 1995, No. 3719-XII. Edict of the President of the Republic of Belarus "On Adoption of the Concept of National Security of the Republic of Belarus," of November 9, 2010, No. 575, Art. 19(5).

15 Roman Petrov, "The Partnership and Co-operation Agreements with the Newly Independent States," in Handbook on European Enlargement: A Commentary on the Enlargement Process, ed. A. Ott and K. Inglis, (The Hague: Asser Press, 2003), 175.

16 Agreement Between the Republic of Belarus and the Commission of the European Communities on the Establishing Privileges and Immunities of the Delegation of the Commission of the European Communities to the Republic of Belarus of March 7, 2008 (entered into force on January 30, 2009); Framework Agreement Between the Commission of the European Communities and the Government of the Republic of Belarus of December 18, 2008; Agreement in the Form of an Exchange of Letters Between the European Community and the Republic of Belarus Amending the Agreement Between the European Community and the Republic of Belarus on Trade in Textile 
the Council of the EU authorized the European Commission to start negotiations on the Visa Facilitation and Readmission Agreements with Belarus, ${ }^{17}$ which are ongoing. ${ }^{18}$

Due to the lack of substantial legal grounds of EU-Belarus relations and, mainly, since the EU has frozen the ratification of the PCA, it can be stated that, on the EU side, the EU-Belarus relations are currently mostly governed by successive conclusions of the EU Foreign Affairs Council.

Regardless of the lack of a bilateral contractual framework, there are binding legal acts adopted in Belarus in order to foster the development of EU-Belarus relations and to encourage the EU to give legal effect to the PCA with Belarus. For example, the Concept of National Security states that Belarus intends to stir up interaction with the EU, ${ }^{19}$ develop full-scale relations with the EU Member States, and to maintain an active dialogue with the EU on the issues of mutual interest with the prospect of concluding the Partnership and Co-operation Agreement as well as "abolition of discriminative measures against the Belarusian state." ${ }^{20}$ Therefore, the Belarusian authorities are indeed interested in concluding the PCA with the EU since this objective forms part of the programme document. If the EU-Belarus PCA (or any other international agreement between the parties) enters into legal force, it would constitute an inherent part of the Belarusian legal order as would any other international agreement. However, this does not mean that its implementation into the legal system of Belarus would take place without legal challenges.

\section{International Law in Belarus}

The Constitution of the Republic of Belarus possesses the highest legal force on the territory of Belarus. It is believed that, according to Napoleon, constitutions should be court et obscure, and, similarly, according to some of the American founding fathers-

Products, OJ, (2007): L 337/114. The last agreement is the renewed 1993 Textile Agreement setting quotas on Belarusian textiles exports. It has been renewed several times but ceased to exist in 2009 .

Council Conclusions on Belarus, 3065th Foreign Affairs Council meeting, Brussels, January 31, 2011; Note from General Secretariat of the Council to Coreper/Council 6354/11, February 18, 2011. Adoption of a Council Decision authorizing the Commission to open negotiations for the conclusion of an agreement between the European Union and Belarus on the facilitation of the issuance of short-stay visas; Note from General Secretariat of the Council to Coreper/ Council 6424/11, February 18, 2011. Adoption of a Council Decision authorizing the Commission to open negotiations for the conclusion of a readmission agreement between the European Union and Belarus.

18 See "Belarus and the EU," accessed May 1, 2018, https://eeas.europa.eu/delegations/ belarus/15975/belarus-and-eu_en.

19 Edict of the President of the Republic of Belarus "On Adoption of the Concept of National Security of the Republic of Belarus," of November 9, 2010, No. 575, Art. 19(5). 
short and obscure. ${ }^{21}$ The Belarus' Constitution is almost twice as long as the American one and it is, arguably, not as "obscure" either. ${ }^{22}$ However, there is an exception. An "obscure" spot of the Belarus' Constitution, which interests us the most for the purposes of this country report, concerns the relation of international law and national law.

The Constitution of Belarus is not clear on the effect of international agreements: "The Republic of Belarus shall recognize the supremacy of the generally recognized principles of international law and shall ensure the compliance of laws therewith." 23 Therefore, the Constitution does not provide for the priority of international agreements and only stipulates that the state shall recognize the supremacy of the universally acknowledged principles of international law and ensure that its laws comply with such principles. It means that the Constitution recognizes the supremacy of the generally recognized principles of international law rather than international agreements and the international law as such within the legal system of Belarus.

Some of these principles are listed:

In its foreign policy the Republic of Belarus shall proceed from the principles of equality of states, non-use of force or threat of force, inviolability of frontiers, peaceful settlement of disputes, non-interference in internal affairs and other generally recognized principles and norms of international law. ${ }^{24}$

Former head of the Constitutional Court believes that the universally acknowledged principles of international law are, in fact, higher than the national Constitution, and the latter must be interpreted in light of the former. ${ }^{25}$

At least as compared to the previous 1978 Constitution of the Byelorussian Soviet Socialistic Republic, which referred to international treaties only with regard to the competence of concluding and ratifying them, the current Constitution recognizes them as a source of law and refers to them six times in the text. ${ }^{26}$ One of the provisions precludes conclusion of international agreements that contradict the Constitution. ${ }^{27}$

21

Günter Frankenberg, “Comparing Constitutions: Ideas, Ideals, and Ideology-toward a Layered

Narrative, “Icon-International Journal of Constitutional Law 4.3 (2006): fn. 2.

Thus, there are no such debatable provisions as "proper and necessary" clause.

Constitution of Belarus, Art. 8(1).

Constitution of Belarus, Art. 18.

Grigoriy A. Vasilevich, Konstitutsionnye osnovy implementatsii mezhdunarodnykh dogovorov

Respubliki Belarus i norm, integratsionnogo prava [Constitutional Basics of Implementation of International Treaties of the Republic of Belarus and Norms of Integration Law] (Minsk: Pravo i ekonomika, 2015), 104.

6 Ivan I. Pliakhimovich, Kommentarii k Konstitutsii Respubliki Belarus [Commentary to the Constitution of the Republic of Belarus] (Minsk: Amalfeia, 2015), 209.

Constitution of Belarus, Art. 8(3). 
Another notion used alongside "international treaties" is "international legal acts." The latter are used in the Constitution in the context of ratification, ${ }^{28}$ but can be understood as including such acts as international agreements and acts of international organizations, as well as international individual legal acts. ${ }^{29}$

The status of international agreements (and here we have in mind the possible international agreement with the EU) is not clearly defined in other national legislative acts either. In principle, it depends on the status of national legal acts, by which such agreements are adopted as binding. According to the Law on International Treaties,

legal norms of international agreements concluded by Belarus form part of national legislation and are subject to direct applicability. This is apart from situations where it follows from the agreement itself that a national legal act should be adopted. In this case, international agreements essentially have the force of the ratifying act. ${ }^{30}$

A similar provision is part of the Law on Normative Legal Acts. ${ }^{31}$ This means that the legal force of Belarus' international agreements is equated to that of national legal acts, by which such agreements are adopted as binding. As a general rule, in case of a collision between legal acts, the act with higher legal force is applicable. However, in case such acts are of equal legal force, the act adopted later takes precedence. Following this rule, as noted by L. Pavlova ${ }^{32}$ and A. Zybailo, ${ }^{33}$ the force of norms of an international agreement on the territory of Belarus can be annulled through adoption of a new law, decree, or edict. Similar provisions are part of the Civil Code, Bank Code, and a number of other legal acts. ${ }^{34}$ Only the Civil Procedure Code, Criminal Code, and Labor Code as

28 Constitution of Belarus, Art. 61, Art. 116 (part 4).

29 Pliakhimovich, "Commentary to the Constitution of the Republic of Belarus," 248.

30 Zakon Respubliki Belarus "O mezhdunarodnykh dogovorakh Respubliki Belarus [On International Treaties of the Republic of Belarus]," of July 23, 2008, No. 4213, Natsionalnyi reestr pravovykh aktov Respubliki Belarus (August 4, 2008), No. 184, 2/1518, Art. 33(2).

Zakon Respubliki Belarus "O normativnykh pravovykh aktakh Respubliki Belarus [On Normative Legal Acts of the Republic of Belarus]," of January 10, 2000, No. 361-Z, Natsionalnyi reestr pravovykh aktov Respubliki Belarus (January 13, 2000) No. 2/136, Art. 20. Liudmila V. Pavlova, “Osobennosti zakonotvorchestva Respubliki Belarus v oblasti zakliucheniia mezhdunarodnykh dogovorov [Features of the Republic of Belarus Law-making in the Field of Conclusion of International Treaties]," in Aktualnyie problem mezhdunarodnogo publichnogo i mezhdunarodnogo chastnogo prava: sbornik nauchnykh trudov, ed. Elena V. Babkina et al. (Minsk: BSU, 2011), 109.

33 Alla I. Zybailo, "Mesto istochnikov prava EvrAzES v pravovykh sistemakh gosudarstv-chlenov [Place of EURASEC Sources of Law in Legal Systems of Member States]," Evraziiskii iuridicheskii zhurnal 7 (2013): 14-18. 
well as a number of other laws give prevalence to international agreements in case of conflict with national legislation. ${ }^{35}$

Therefore, according to these rules, the possible international agreement with the EU, which would have to be ratified by a national law, could in principle become lower in status than a future new act of national legislation. Hence, there is nothing to prevent the rule lex posterior derogate legi priori. However, Vasilevich believes that this principle does not apply, but the principle lex specialis derogate legi generali applies instead. ${ }^{36}$ In this case, international agreements enjoy priority over any kind of laws, while still remaining lower than the Constitution, essentially claiming that the legislative provisions mentioned above are unconstitutional. ${ }^{37}$ At any rate, it is plausible that international law-friendly interpretation would give prevalence to such an international agreement over national legislation.

In terms of direct applicability of international agreements, although the Constitution does not provide for a relevant formulation, article 116 can be interpreted in such a manner. This is because the Constitutional Court can recognize the President's laws, decrees, and edicts as unconstitutional if they do not conform to ratified international legal acts. ${ }^{38}$

In any event, the overview above shows regulatory deficiencies regarding the status of international agreements in the national law of Belarus.

\section{The Issues of the World Trade Organization Law}

The EU supports Belarus in its bid to become member of the World Trade Organization (WTO) and helps it by providing technical assistance through the TAIEX twinning

of International Law."

Code of Civil Procedure of the Republic of Belarus, of January 11, 1999, No. 2383, Art. 543; Criminal Code of the Republic of Belarus, of July 9, 1999, No. 2753, Art. 7 (regarding extradition); Labor Code of the Republic of Belarus, adopted on July 26, 1999, No. 2963, Art. 8 (regarding agreements that are ratified and entered into force); Criminal Enforcement Code of the Republic of Belarus, of January 11, 2000, No. 3653, Art. 3 (prioritizes self-executive norms of international agreements). See also the Investment Code of the Republic of Belarus, of June 22, 2001, No. 373, Art. 6(3); Marriage and Family Code of the Republic of Belarus of July 9, 1999, No. 2783, Art. 237; Tax Code of the Republic of Belarus of December 19, 2002, No. 1663, Art. 5; Air Code of the Republic of Belarus of May 16, 2006, No. 1173, Art. 4; and others.

36 Vasilevich, Constitutional Basics of Implementation of International Treaties of the Republic of Belarus and Norms of Integration Law, 124.

37 Vasilevich, Constitutional Basics of Implementation of International Treaties of the Republic of Belarus and Norms of Integration Law, 37; Pliakhimovich, Commentary to the Constitution of the Republic of Belarus, 244.

38 Art. $116(5)$. 
instrument. ${ }^{39}$ However, interestingly enough, WTO law is already applicable in Belarus, even though Belarus is not a member yet.

This situation occurs in virtue of Belarus' membership to the EAEU. Annex 31 to the EAEU Treaty provides for the Protocol on the Functioning of the EAEU within the Multilateral Trading System..$^{40}$ It refers to the Treaty on the Functioning of the Customs Union within the Multilateral Trading System concluded on 19 May 2011. ${ }^{41}$ This essentially extends its validity and introduces it into the EAEU legal framework. The Treaty on the Functioning of the Customs Union within the Multilateral Trading System (hereinafter "Multilateral Trading System Agreement") was adopted to accommodate accession of the Customs Union member states into the WTO and, primarily, Russia, who was to accede first. Russia eventually acceded in $2012,{ }^{42}$ and its obligations became part of the EAEU law in virtue of Article 1(1) of the Multilateral Trading System Agreement:

From the date of accession of any of the Parties to the WTO, the provisions of the WTO Agreement as set out in its Protocol of Accession, including the commitments undertaken by this Party as part of the terms of its accession to the WTO, which relate to matters that the Parties have authorized Customs Union Bodies to regulate in the framework of the Customs Union, as well as the legal relationships, regulated by the international treaties, constituting the legal framework of the Customs Union, shall become a part of the legal framework of the Customs Union. ${ }^{43}$

Thus, the WTO Agreement is part of the law of the Union in part, which is covered by the exclusive competence of the EAEU on the conditions of the first member state acceding to the WTO, meaning Russia. Further, upon accession of other member states to the WTO, their obligations also become part of Union law.

This means that even though Belarus is not part of the WTO, it is bound by WTO legal norms. Although, there are caveats. Member states that are not part of the WTO are allowed to deviate from WTO law, to the extent that (1) EAEU law is required to be adjusted; and/or (2) national legal order autonomously regulates the matter in hand. To take advantage of this exception, Belarus would have to notify the Eurasian Economic

See "Belarus and the EU," accessed May 1, 2018, https://eeas.europa.eu/delegations/ belarus/15975/belarus-and-eu_en.

Annex 31 to the Treaty on the Eurasian Economic Union. Protocol on the Functioning of the Eurasian Economic Union within the Multilateral Trading System.

41 Treaty on the Functioning of the Customs Union in the Framework of the Multilateral Trading System of May 19, 2011.

42 See "Russian Federation and the WTO," accessed May 1, 2018, https://www.wto.org/english/ thewto_e/countries_e/russia_e.htm.

43 Art. 1(1) Treaty on the Functioning of the Customs Union in the Framework of the Multilateral Trading System. 
Commission of the nature and extent of such deviations. Such exceptions cease to exist upon accession of Belarus to the WTO, unless it is expressly provided for by the terms of accession to the WTO. ${ }^{4}$

Further, WTO law has priority over EAEU law until the latter is amended to comply with the former. ${ }^{45}$ The rights and obligations of the Member States stemming from WTO law cannot be abrogated or limited by Eurasian Economic Commission decisions and international agreements within the EAEU or by the EAEU Court. ${ }^{46}$

Therefore, it is a rather interesting development in the binding legal framework which could be used beneficially by both the EU and Belarus in their trade relations.

\section{Legal Aspects of Belarus-EU Relations in Light of Participation in the EAEU}

Delving deeper into Belarus participation in the EAEU, it must be noted that EAEU is "an international organization of regional economic integration and shall have international legal personality." ${ }^{47 T h e}$ latter means that the EAEU can conclude international agreements. This does not preclude Belarus from concluding international agreements as long as they do not conflict with the aims and principles of the EAEU Treaty: "This Treaty shall not preclude the conclusion by the Member States of international treaties that are not inconsistent with the objectives and principles of this Treaty." 48

The EU is Belarus second main trading partner, and the bilateral trade in goods has been growing. So far, the Dialogue on Trade has been established, which serves the purpose of exchanging on regulatory issues and trade concerns.${ }^{49}$ Concluding any international agreement between the EU and Belarus would require taking into consideration the competence of the EAEU. This is especially true of any agreements that would include trade in goods, since customs union policy is an exclusive competence of the EAEU.

Indeed, the EAEU Treaty identifies three types of policies: common policy, coordinated policy, and agreed policy. A common policy is:

the policy implemented by the Member States in certain spheres as specified in this Treaty and envisaging the application of unified

44 Art. 1(6) Treaty on the Functioning of the Customs Union in the Framework of the Multilateral Trading System.

Art. 2(1) Treaty on the Functioning of the Customs Union in the Framework of the Multilateral Trading System.

46 Art. 2(2) Treaty on the Functioning of the Customs Union in the Framework of the Multilateral Trading System.

47 Art. 1(2) Treaty on the Eurasian Economic Union.

48 Art. 114(1) Treaty on the Eurasian Economic Union.

49 See "Belarus and the EU," accessed May 1, 2018, https://eeas.europa.eu/delegations/ belarus/15975/belarus-and-eu_en. 
legal regulations by the Member States, including on the basis of decisions issued by Bodies of the Union within their powers. ${ }^{50}$

In its advisory opinion, the EAEU Court has clarified that in order to ascribe certain spheres to a common policy, two conditions must be met: first, a unified legal framework must be present; second, member states must have conferred competences in this sphere to the bodies of the Union within their supranational powers. ${ }^{51}$ Thus, the notion of common policy corresponds broadly to that of exclusive competence in the EU.52 The EAEU Court has identified a number of policy areas that correspond to these criteria, and one of them is indeed the customs union policy as it requires a unified legal regime and transfer of competence from the member states to the EAEU.53

Thus, EAEU's involvement would be needed in a number of fields, which is complicated since there are no official relations between the EAEU and EU. ${ }^{54}$ This would not be easy for legal reasons as well, since the EAEU possesses its own complex legal system and a totality of legal rules collected under the notion of the "law of the Union." 55 The EAEU has developed its own rules for conclusion of international agreements, and has been active in pursuing external trade and economic cooperation. It has also launched a process for a network of free trade agreements of its own. The first such agreement was concluded with Vietnam in $2015 .{ }^{56}$ The work is underway to negotiate further agreements with a number of other states. ${ }^{57}$

\footnotetext{
$50 \quad$ Art. 2 Treaty on the Eurasian Economic Union.

$5^{1}$ Advisory Opinion N SE-2-1/1-17-BK, April 4, 2017. This view has been confirmed in the future cases, e. g. Advisory Opinion N SE-2-2/2-17-BK, October 30, 2017. 


\section{Conclusion}

Belarus is not well integrated into the framework of common European values, standards, and legal rules compared to other members of the Eastern Partnership and beyond. Belarus has never voiced European aspirations preferring instead deeper integration with Russia. It seems that only during times of conflict with its Eastern neighbor has the Belarusian leadership turned to somewhat more pro-European rhetoric, though without any considerable implications.

Recently, some changes have occurred and the dialogue is growing. Belarus is trying to position itself as capable of being an equal partner to anyone and to balance its interests between the East and the West. This has not led to an overhaul of the contractual legal framework with the EU yet, which is still based on some outdated agreements and provisions. It seems that there is a growing interest on both sides and changes might follow. Until this happens, there are certain legal assurances for beneficial relations, which surprisingly flow from Belarus' membership in the EAEU. This is particularly true in the applicability of WTO law in Belarus, albeit the country is not a member thereof.

Although some new contractual legal framework between Belarus and the EU is imaginable, a comprehensive agreement is hardly possible. It follows primarily from Belarus' membership in the EAEU and its transfer of certain exclusive competences to the supranational level. This means that any comprehensive agreement with the EU would need involvement of the EAEU.

\section{Bibliography}

Advisory Opinion N SE-2-1/1-17-BK, April 4, 2017.

Advisory Opinion N SE-2-2/2-17-BK, October 30, 2017.

Agreement Between the European Community and the European Atomic Energy

Community and the Union of Soviet Socialist Republics on Trade and Commercial and Economic Cooperation, OJ, (1990): L 68/3.

Agreement Between the Republic of Belarus and the Commission of the European Communities on the Establishing Privileges and Immunities of the Delegation of the Commission of the European Communities to the Republic of Belarus. March 7, 2008 (entered into force on January 30, 2009).

Agreement in the Form of an Exchange of Letters between the European Community and the Republic of Belarus Amending the Agreement Between the European Community and the Republic of Belarus on Trade in Textile Products, OJ, (2007): L 337/114.

Air Code of the Republic of Belarus. May 16, 2006, No. 1173.

Annex 31 to the Treaty on the Eurasian Economic Union. Protocol on the Functioning of the Eurasian Economic Union within the Multilateral Trading System.

Bank Code of the Republic of Belarus, adopted on October 25, 200o, No. 4413.

"Belarus and the EU." Accessed May 1, 2018. https://eeas.europa.eu/delegations/ belarus/15975/belarus-and-eu_en. 
Code of Civil Procedure of the Republic of Belarus. January 11, 1999, No. 2383.

Council Conclusions on Belarus, 3065th Foreign Affairs Council Meeting, Brussels, January 31, 2011.

Civil Code of the Republic of Belarus, adopted on December 7, 1998, No. 2183.

Criminal Enforcement Code of the Republic of Belarus. January 11, 2000, No. 3653.

Criminal Code of the Republic of Belarus. July 9, 1999, No. 2753.

Edict of the President of the Republic of Belarus "On Adoption of the Concept of National Security of the Republic of Belarus." November 9, 2010, No. 575, Art. 19(5).

Elsuwege, Peter Van, "The European Union and the Belarus Dilemma: Between Conditionality and Constructive Engagement," Proceedings of the Institute for European Studies, Journal of Tallinn University of Technology 7 (2010): 7-20.

Enactment of the Supreme Council of the Republic of Belarus "On Ratification of the Partnership and Cooperation Agreement Between the European Communities and their Member States of the One Part, and Belarus, on the Other Part." April 12, 1995, No. 3719-XII.

"EU-Belarus Relations Fact Sheet." Accessed May 1, 2018. http://eeas.europa.eu/ delegations/belarus/eu_belarus/political_relations/index_en. htm.

"European Union—Restrictive Measures (Sanctions) in Force." Accessed May 1, 2018. http://eeas.europa.eu/cfsp/sanctions/docs/measures_en.pdf.

Framework Agreement Between the Commission of the European Communities and the Government of the Republic of Belarus. December 18, 2008.

Frankenberg, Günter, "Comparing Constitutions: Ideas, Ideals, and Ideology-toward a Layered Narrative. “ Icon-International Journal of Constitutional Law 4.3 (2006): fn. 2.

Free Trade Agreement Between the Eurasian Economic Union and its Member States, of the One Part, and the Socialist Republic of Viet Nam, of the Other Part. May 29, 2015.

"Human Rights." Accessed May 1, 2018. http://mfa.gov.by/en/organizations/human_ rights/.

Investment Code of the Republic of Belarus. June 22, 2001, No. 373.

Karliuk, Maksim. "The Constitutional Order of Belarus and Its Adaptability to the Eurasian Economic Union: A 'Living Constitution' Workaround.” In Post-Soviet Constitutions and Challenges of Regional Integration: Adapting to European and Eurasian Integration Projects, edited by Roman Petrov and Peter Van Elsuwege, 174-96. Oxford: Routledge, 2018.

Karliuk, Maksim. "Legislative Approximation and Application of Eu Law in Belarus." In Legislative Approximation and Application of Eu Law in the Eastern Neighbourhood of the European Union: Towards a Common Regulatory Space?, edited by Roman Petrov and Peter Van Elsuwege, 203-18. Oxford: Routledge, 2014.

"Makei: Belarus Ready for New Framework Agreement with EU." Accessed December 26, 2016. http://www.belta.by/politics/view/belarus-hochet-zakljuchit-s-es-novoesoglashenie-dlja-razvitija-otnoshenij-176293-2016/.

Labor Code of the Republic of Belarus, adopted on July 26, 1999, No. 2963. 
Marriage and Family Code of the Republic of Belarus. July 9, 1999, No. 2783.

Pavlova, Liudmila V. "Osobennosti zakonotvorchestva Respubliki Belarus v oblasti zakliucheniia mezhdunarodnykh dogovorov [Features of the Republic of Belarus Law-making in the Field of Conclusion of International Treaties]." In Aktualnyie problemy mezhdunarodnogo publichnogo i mezhdunarodnogo chastnogo prava: sbornik nauchnykh trudov, edited by Elena V. Babkina et al., 102-11. Minsk: BSU, 2011.

Petrov, Roman. "The Partnership and Co-operation Agreements with the Newly Independent States." In Handbook on European Enlargement: A Commentary on the Enlargement Process, edited by A. Ott and K. Inglis, 175-94. The Hague: Asser Press, 2003.

Pliakhimovich, Ivan I. Kommentarii k Konstitutsii Respubliki Belarus [Commentary to the Constitution of the Republic of Belarus]. Minsk: Amalfeia, 2015.

Proposal for a Council and Commission Decision on the Conclusion of the Partnership and Cooperation Agreement Between the European Communities and their Member States, of the One Part, and Belarus, of the Other Part. February 22, 1995, COM (95) 44 final.

"Russian Federation and the WTO." Accessed May 1, 2018. https://www.wto.org/english/ thewto_e/countries_e/russia_e. htm.

"Status of Negotiation Tracks on Free Trade." Accessed December 23, 2018. http://www.eurasiancommission.org/ru/act/trade/dotp/sogl_torg/ Documents/\%do\%a1\%d1\%82\%do\%bo\%d1\%82\%d1\%83\%d1\%81\%20 \%do\%bf\%do\%be\%2o\%do\%bf\%do\%b5\%di\%8o\%do\%b5\%do\%b3\%do \%be\%do\%b2\%do\%be\%dı\%8○\%do\%bd\%dı\%8b\%do\%bc\%20\%dı\%82\%dı\%8 ○\%do\%b5\%do\%ba\%do\%b○\%do\%bc.pdf.

Sytas, Andrius. "Exclusive: EU's Juncker Dangles Trade Ties with Russia-Led Bloc to Putin.” Accessed May 1, 2018. http://www. reuters. com/article/us-eu-junckerrussia-idUSKCN oT821T20151119.

T-438/11: Action brought on August 12, 2011-BelTechExport v. Council. O. J. C 29o, o1/10/2011 P. o015-0015.

T-439/11: Action brought on August 12, 2011 — Sport-pariv. Council. O. J. C 29o, 01/10/2011 P. oo15-0016.

T-44O/11: Action brought on August 12, 2011-BT Telecommunications v. Council. O. J. C 29o, 01/10/2011 P. 0016-0017.

T-441/11: Action Brought on August 12, 2011-Peftiev v. Council. O. J. C 29o, o1/10/2011 P. o017-0017.

Tax Code of the Republic of Belarus of December 19, 2002, No. 1663.

The Constitution of the Republic of Belarus, adopted on May 15, 1994, No. 2875-XII (as amended by the republican referendums on November 24, 1996, October 17, 2004).

Treaty on the Functioning of the Customs Union in the Framework of the Multilateral Trading System. May 19, 2011. 
Vasilevich, Grigoriy A. Konstitutsionnye osnovy implementatsii mezhdunarodnykh dogovorov Respubliki Belarus i norm, integratsionnogo prava [Constitutional Basics of Implementation of International Treaties of the Republic of Belarus and Norms of Integration Law]. Minsk: Pravo i ekonomika, 2015.

Zakon Respubliki Belarus "O mezhdunarodnykh dogovorakh Respubliki Belarus [On International Treaties of the Republic of Belarus]." July 23, 2008, No. 4213, Natsionalnyi reestr pravovykh aktov Respubliki Belarus (August 4, 2008) No. 184, 2/1518.

Zakon Respubliki Belarus "O normativnykh pravovykh aktakh Respubliki Belarus [On Normative Legal Acts of the Republic of Belarus]." January 10, 2000, No. 361-Z, Natsionalnyi reestr pravovykh aktov Respubliki Belarus (January 13, 2000) No. 2/136. Zybailo, Alla I. "Mesto istochnikov prava EvrAzES v pravovykh sistemakh gosudarstvchlenov [Place of EURASEC Sources of Law in Legal Systems of Member States]," Evraziiskii iuridicheskii zhurnal 7 (2013): 14-18.

\section{汿}

Maksim Karliuk holds an LLM in European Law (College of Europe, Bruges, 2011) and a specialist degree in International and European Law (Belarusian State University, 2010). His research activities focus on regulatory impact assessment, legal approximation, Eurasian integration and EU external relations law. 